\title{
RESEARCH PAPERS
}

\section{Optimization of DNA extraction protocol using skeletal remains found in Sri}

\section{Lanka}

\author{
Chandimal, K.M. ${ }^{1}$, Yasawardene, S.G. ${ }^{2}$, Ruwan, J. Illeperuma ${ }^{3}$ \\ ${ }^{I}$ Department of Anatomy, Faculty of Medicine, Wayamba University, Sri Lanka. \\ ${ }^{2}$ Department of Anatomy, Faculty of Medical Sciences, University of Sri \\ Jayewardenepura, Sri Lanka \\ ${ }^{3}$ Molecular Forensic Unit, Genetech, Colombo 08, Sri Lanka
}

\begin{abstract}
\section{Introduction}

The preservation of DNA in old skeletal remains is reported to be very low in a tropical country like Sri Lanka due to prevailing climatic and environmental conditions such as high temperature, high rainfall and high humidity, etc. In this study, extraction of DNA from old skeletal remains dated back to $15-40$ years was attempted by using previously published extraction protocols.
\end{abstract}

\section{Materials and Methods}

A 15-years-old humerus (15Y) excavated from Kuliyapitiya area in Kurunegala district and the 40-yearsold tibia (40Y) received from Department of Anatomy, Faculty of Medical Sciences, University of Sri Jayewardenepura were used to extract old DNA. Human mitochondrial HVS I region of extracted DNA was amplified in PCR using four overlapping first round primers and second round nested primers respectively. A second-round nested PCR was performed. PCR amplification success was verified upon electrophoresis in 2\% agarose gels.

\section{Results and Analysis}

DNA bands were obtained with correct size ranges for all systems in both first and second round PCR products of amplified DNA extract of old bones $15 \mathrm{Y}$ and $40 \mathrm{Y}$ from modified phenolchloroform method. DNA bands were obtained from all four systems for $40 \mathrm{Y}$ bone DNA extract from DNA investigation Kit; QIAGEN, Germany.

\section{Conclusion}

In the present study, we have successfully extracted and amplified DNA from old skeletal remains by using modified phenol chloroform method and DNA investigation Kit QIAGEN, Germany, nevertheless the preservation of DNA in skeletal remains in Sri Lanka is very low.

Keywords - Old DNA, Bone DNA extraction protocols, Forensic medicine, 
Chandimal, K.M., Yasawardene, S.G., Ruwan, J. Illeperuma - Optimization of DNA extraction protocol using skeletal remains found in Sri Lanka

\section{Introduction}

Nucleic acids in biological material are subjected to degradation and modification due to exposure to water, oxygen and, microbes and thus the survival of DNA in forensic remains/archaeological remains depends on geographical, climatic, environments and soil conditions. ${ }^{[1,2,3]}$ The low preservation of DNA in forensic remains of old bones/teeth and their authenticity are the two main inherent problems recognized in extraction and analysis of old DNA. ${ }^{[4]}$

Nucleic acids slowly degrade over time mainly through processes of hydrolysis and oxidation. ${ }^{[2,5]}$ Hydrolysis breakdown the N-glycosyl bond between the sugar and the base of DNA strand in the presence of water. Oxidation modify bases or distort the helix due to hydroxyl or superoxide radicals. As oxygen metabolism in the cell is taken place within the mitochondria, oxidation mainly affects the mitochondrial DNA compared to the nuclear DNA. ${ }^{[6]}$

Hydantoins (oxidized pyrimidines) are mostly done the destruction to DNA. ${ }^{[6]}$ Hydantoins decreases the success in extraction and amplification of DNA in old and ancient skeletal remains. They particularly inhibit chain extension in $\mathrm{PCR}^{[7]}$. Therefore, recovery and, amplification of DNA in old bones, when possible, is usually limited to fragments of having sizes range from 300 to 500 bp in length ${ }^{[6]}$.

The presence of a mineral matrix of hydroxyapatite which surrounds the osteon, preserves its DNA, therefore bone is generally considered an optimal DNA source for DNA studies in old samples $^{[2,8,9]}$. Literature further supports that bones give better DNA yield than that of other soft tissues of the human $\operatorname{body}^{[10,11]}$.

Globally, several DNA extraction protocols have been developed for old and ancient samples ${ }^{[4,12,13,14,15,16,17,18,19]}$. The Chelex based DNA extraction protocol has been attempted to extract highly fragmented aDNA from human and animal skeletal remains dated back to 5,400 YBP at temperate countries like Canada by Newman et al., (2002) ${ }^{[13]}$. The method of ethanol precipitation enhanced by Dextran blue has yielded aDNA of skeletal remains found in Iran in the Middle East ${ }^{[14]}$. Phenolchloroform method has been used to successfully extract aDNA not only from Neanderthal infant (29,000 YBP) excavated from Russia but also from human bone samples (600-year-old) found in Malaysia situated near to equator ${ }^{[19,14]}$.

The preservation of DNA in old or even archaeological remains in tropical countries like Sri Lanka is very low and the amount of recoverable DNA is scanty $^{[20]}$. There are no documented studied done on successful extractions of DNA from old skeletal remains found in Sri Lanka. Therefore, the development of an efficient method to recover DNA from old skeletal remains found in a tropical county like Sri Lanka is timely needed. 
Chandimal, K.M., Yasawardene, S.G., Ruwan, J. Illeperuma - Optimization of DNA extraction protocol using skeletal remains found in Sri Lanka

\section{Materials and Methods}

\section{Precautions to avoid contamination during DNA extractions}

All extractions and PCR activities both pre and post were performed in three separate rooms with dedicated equipment according to the guidelines given for analysis of old and ancient $\mathrm{DNA}^{[4]}$. Physically isolated clean room was dedicated to DNA experiments for all manipulations prior to PCR. Access to DNA extraction room was strictly controlled according to the guidelines given by Paabo et al., 2004; Amory et al., 2012; and Zgonjanin et al., $2017^{[4,21,22]}$

Preparations reagents, bone grinding, DNA extractions and PCR were performed in laminar floor hood equipped with UV bulbs. The laminar floor hood was cleaned with $10 \%$ bleach, $96 \%$ ethanol and UV irradiated before each use.

Barrier tips/aerosol-resistant tips were used in reagent preparation, DNA extraction and PCR and other all steps. Solutions used for DNA extraction, PCR reagents and post PCR reagent were stored in isolated rooms. Bone processing and DNA extraction was carried out in separate room.

Polymerase Chain Reaction (PCR) was set up in a room dedicated for this sole purpose and post PCR gel

electrophoresis was carried out in a third room.

The use of masks, coats, gloves and the use of disposable sterile materials for all manipulation were done to minimize potential contaminations. A negative control containing blank DNA extraction was performed along with each batch of extractions to eliminate contaminations during DNA extractions. A second negative control was used in PCR to verify the extraction and PCR authenticity ${ }^{[21,23]}$.

\section{Bone samples analysed}

A 15-years-old humerus (15Y) excavated from Kuliyapitiya area in Kurunegala district and the 40-yearsold tibia (40Y) received from Department of Anatomy, Faculty of Medical Sciences, University of Sri Jayewardenepura were used to extract DNA.

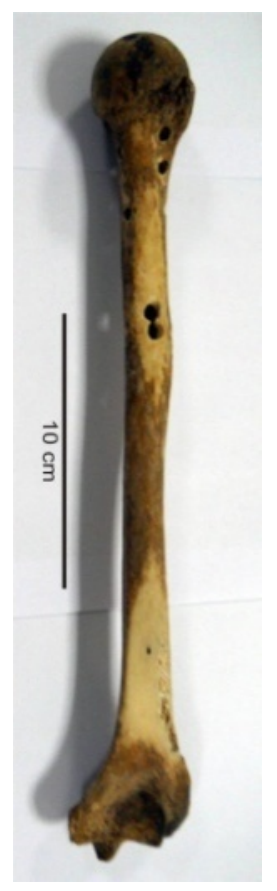

$15 \mathrm{Y}$

15 Y (15-years-old humerus)

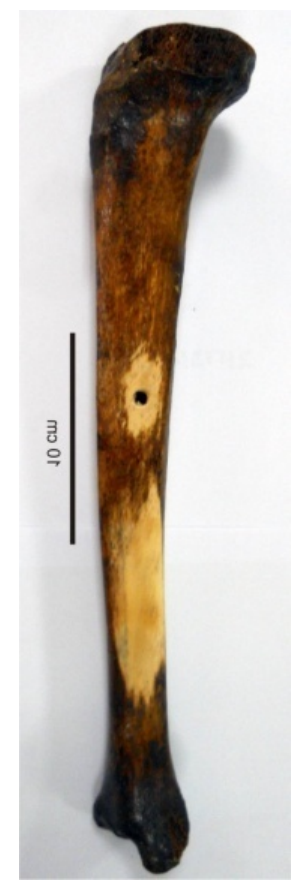

$40 \mathrm{Y}$
40 Y (40-years-old tibia)

\section{Bone samples used in extractions}


Chandimal, K.M., Yasawardene, S.G., Ruwan, J. Illeperuma - Optimization of DNA extraction protocol using skeletal remains found in Sri Lanka

\section{Preparation of bones for DNA extraction}

The preparation of bone was done according to the methods described by the Amory et al., (2012) ${ }^{[21]}$. The work station and all bone scraping tools were thoroughly cleaned with a freshly prepared $10 \%$ bleach solution followed by washing with $96 \%$ ethanol.

The selected bones were washed thoroughly with household bleach and distilled water respectively at least for two times and followed by air dried. The area of sampling was cleaned by using a sterile and UV irradiated sandpaper which has been stored in $-20 \mathrm{oC}$ to remove the outer most bone surface to remove contaminants and other impurities. Then the purified bone surface was exposed to UV for 15 minutes. The UV irradiated surface was used to make fine powdered bone sample by using UV irradiated sandpaper.

\section{DNA extraction protocols}

Extraction of DNA from skeletal remains was attempted by using previously published extraction protocols such as Chelex ${ }^{[13]}$, ethanol precipitation by Dextran blue $e^{[14]}$, modified ethanol precipitation by Dextran blue ${ }^{[14]}$, modified phenolchloroform method ${ }^{[15]}$ and one commercially available DNA extraction kit (DNA Investigation Kit; QIAGEN, Germany). Five extraction protocols were tried out to extract DNA of $15 \mathrm{Y}$ and $40 \mathrm{Y}$ bone samples.

\section{PCR amplification of the human mtDNA HVS - I}

The hypervariable segment - I in the human mitochondrial D - loop between the positions L15,978 and H16,355 of extracted bone DNA was amplified using first (1st) round oligonucleotide PCR primers Hum1.1, Hum1.2 and Hum 1.3 each of which generating fragment sizes of $378 \mathrm{bp}, 247 \mathrm{bp}$ and 233 bp respectively ${ }^{[24]}$. PCRs were performed in $50 \mu 1$ reaction volumes using $5 \mu \mathrm{l}$ of extracted mitochondrial DNA per reaction in GeneAmp 9,600 thermal cycler (Applied Biosystems) using PCR amplification protocol as reported in Lertrit et al., $2008^{[24]}$.

The second $\left(2^{\text {nd }}\right)$ round PCR was performed with 50 times diluted primary products by using Hum2.1, Hum2.2, Hum2.3 and Hum2.4. Each reaction generated fragment sizes of 247 bp, 135 bp, 161 bp, 228 bp respectively ${ }^{[24]}$. The second round PCR was performed in $50 \mu 1$ reaction volumes using PCR amplification protocol as reported in Lertrit et al., $2008^{[24]}$. Blank reactions were concurrently done for every PCR reaction in order to verify the reliability of the PCR process.

Verification of the success of $2^{\text {nd }}$ round PCR products was performed by running the PCR products along with a DNA size maker (50bp size marker) in a $2 \%$ agarose gel in 0.5 TBE, $\mathrm{pH}-8$ at $100 \mathrm{v}$ for 45 minutes after PCR amplification. 
Chandimal, K.M., Yasawardene, S.G., Ruwan, J. Illeperuma - Optimization of DNA extraction protocol using skeletal remains found in Sri Lanka

\section{Results and Analysis}

DNA was extracted from the old human bones of 15 years (15Y) and 40 years (40Y) by adopting the extraction methods of Chelex ${ }^{[13]}$, ethanol precipitation with Dextran blue ${ }^{[14]}$, modified ethanol precipitation with Dextran blue, modified phenolchloroform method ${ }^{[15]}$ and with a commercially available DNA extraction kit (DNA Investigation Kit - QIAGEN, Germany). The DNA was subjected to PCR amplifications. The success of each PCR amplification reaction was verified by $2 \%$ agarose gel electrophoresis.

\section{Chelex based method}

DNA was extracted from old bones of $15 \mathrm{Y}$ and $40 \mathrm{Y}$ using the method described by Newman et al., (2002). Seven point five microlitres of first and second round of PCR products were subjected to electrophoresis in a $2 \%$ agarose gel. First round products generated fragment sizes of $378 \mathrm{bp}, 247$ bp and $233 \mathrm{bp}$ for $\left(1^{\mathrm{st}}\right)$ round oligonucleotide PCR primers Hum1.1, Hum1.2 and Hum1.3 respectively. Second round products generated fragment sizes of $247 \mathrm{bp}, 135 \mathrm{bp}, 161$ bp, 228 bp for $\left(2^{\text {nd }}\right)$ round oligonucleotide PCR primers Hum2.1, Hum2.2, Hum2.3 and Hum2.4 respectively.

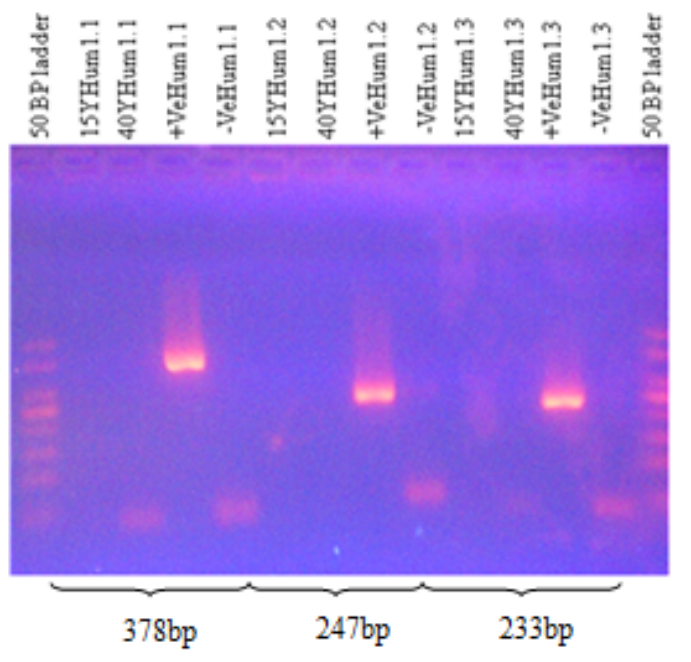

Fig 1.1a

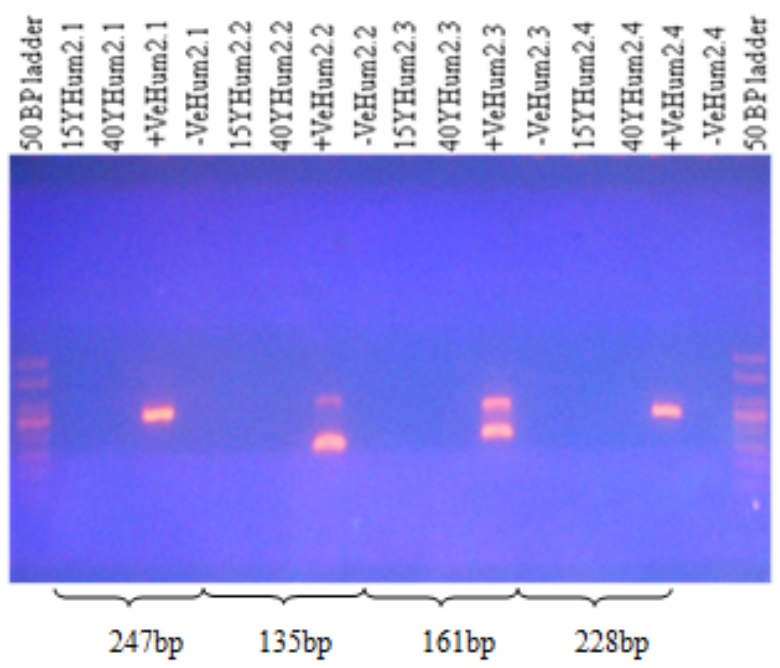

Fig $1.1 \mathrm{~b}$

Fig 1.1a Agarose gel containing $7.5 \mu \mathrm{l}$ of each first round PCR product and Fig $1.1 \mathrm{~b}$ Agarose gel containing $7.5 \mu 1$ of each second round PCR product amplified from the extraction method described by Newman et al., (2002) [13] of $15 \mathrm{Y}$ and $40 \mathrm{Y}$ bones

PCR amplifications were not observed in the first round and second round amplifications of the DNA extracts obtained from the method described by Newman et al., (2002)[13]. This methodology is not success in DNA extraction from old skeletal remains. 
Chandimal, K.M., Yasawardene, S.G., Ruwan, J. Illeperuma - Optimization of DNA extraction protocol using skeletal remains found in Sri Lanka

\section{Ethanol precipitation with Dextran blue based method}

DNA was extracted from modern bones $15 \mathrm{Y}$ and $40 \mathrm{Y}$ using the method described by Mohendasan et al., (2004) ${ }^{[14]}$. Seven point five microlitres of first and second round of PCR products were subjected to electrophoresis in a $2 \%$ agarose gel. First round products

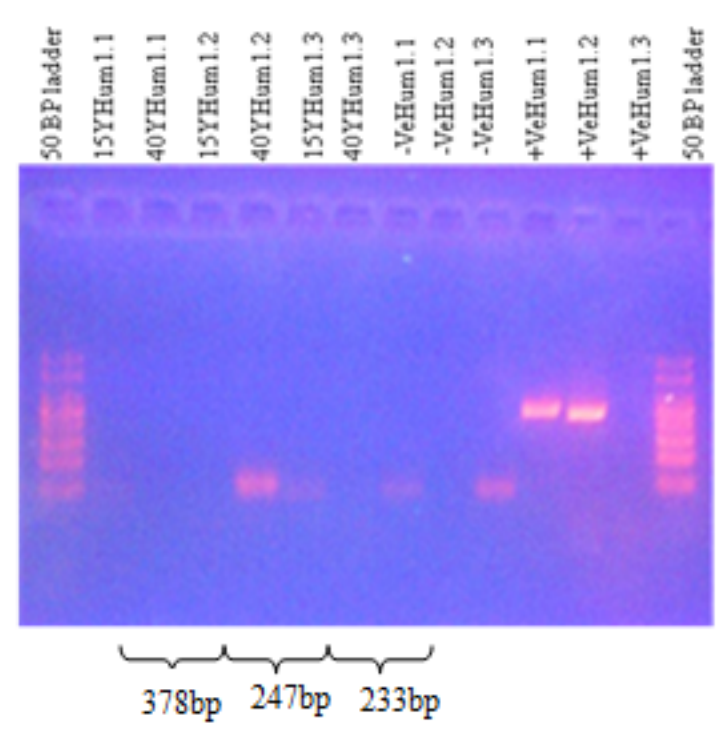

Fig $1.2 \mathrm{a}$

Fig 1.2a Agarose gel containing $7.5 \mu 1$ of each first-round PCR product and Fig 1.2b. Agarose gel containing $7.5 \mu \mathrm{l}$ of each second round PCR product amplified from the extraction method described by Mohendasan et al., (2004) ${ }^{[14]}$ of $15 \mathrm{Y}$ and $40 \mathrm{Y}$ bones

PCR amplifications were not observed in the first round and second round amplifications of the DNA extracts obtained from the method described by Mohendasan et al., (2004) ${ }^{[14]}$. This methodology fails to extract DNA from old skeletal remains. generated fragment sizes of $378 \mathrm{bp}, 247$ bp and $233 \mathrm{bp}$ for $\left(1^{\text {st }}\right)$ round oligonucleotide PCR primers Hum1.1, Hum1.2 and Hum1.3 respectively. Second round products generated fragment sizes of $247 \mathrm{bp}, 135 \mathrm{bp}, 161$ bp, $228 \mathrm{bp}$ for (2nd) round oligonucleotide PCR primers Hum2.1, Hum2.2, Hum2.3 and Hum2.4 respectively.

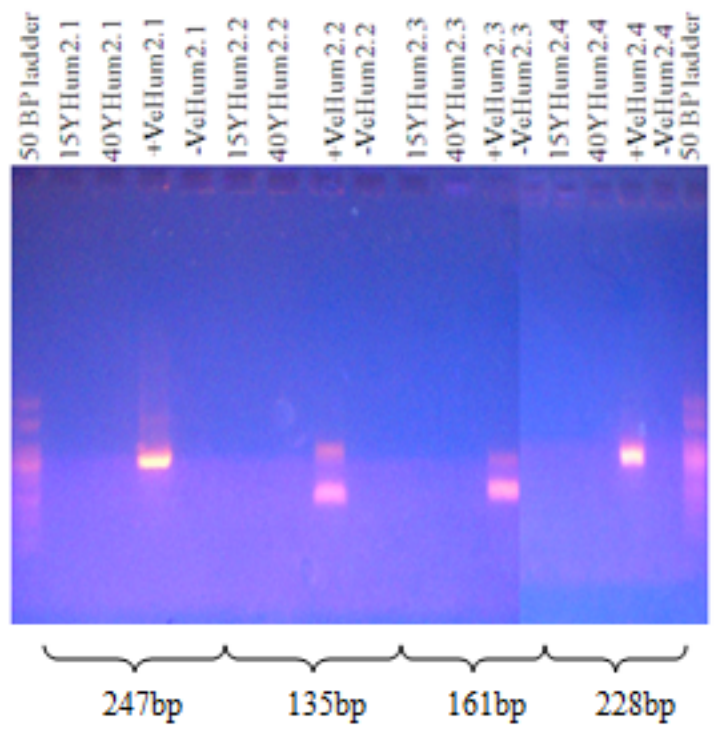

Fig 1.2b

\section{Modified ethanol precipitation with Dextran blue based method}

DNA was extracted from old bones of $15 \mathrm{Y}$ and $40 \mathrm{Y}$ using the modified ethanol precipitation with dextran blue method described by Mohendasan et al., (2004) ${ }^{[14]}$. Seven point five microlitres of each first and second round PCR products were subjected to electrophoresis in a $\%$ agarose gel. First round products generated fragment sizes of $378 \mathrm{bp}, 247 \mathrm{bp}$ and $233 \mathrm{bp}$ for $\left(1^{\text {st }}\right)$ round oligonucleotide PCR primers Hum1.1, Hum1.2 and 
Chandimal, K.M., Yasawardene, S.G., Ruwan, J. Illeperuma - Optimization of DNA extraction protocol using skeletal remains found in Sri Lanka

Hum1.3 respectively. Second round products generated fragment sizes of 247 bp, 135 bp, 161 bp, 228 bp for



Fig 1.3a

Fig 1.3a. Agarose gel containing 7.5 $\mu 1$ of each first round PCR product and Fig 1.3b. Agarose gel containing $7.5 \mu \mathrm{l}$ of each second round PCR product amplified from the modified extraction method described by Mohendasan et al., (2004) ${ }^{[14]}$ of $15 \mathrm{Y}$ and $40 \mathrm{Y}$ bones

PCR amplifications were not observed in the first round PCR amplification of DNA extracts from the modified method described by Mohendasan et al., (2004) ${ }^{[14]}$. DNA bands were obtained with correct size ranges for all systems of second round PCR products.

\section{DNA investigation Kit (QIAGEN,} Germany)

DNA was extracted from old bones of $15 \mathrm{Y}$ and $40 \mathrm{Y}$ using commercially $\left(2^{\text {nd }}\right)$ round oligonucleotide PCR primers Hum2.1, Hum2.2, Hum2.3 and Hum2.4 respectively.

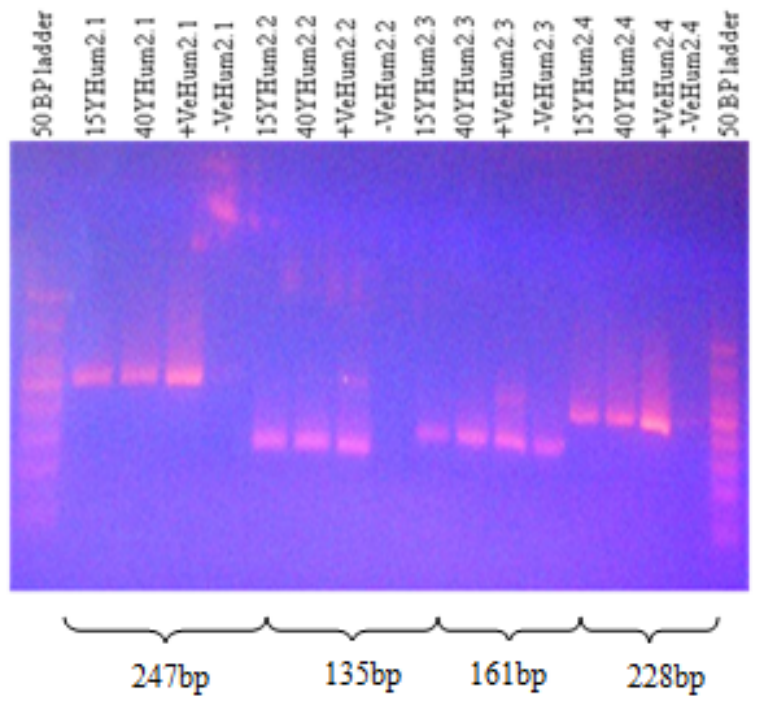

Fig $1.3 \mathrm{~b}$

available DNA extraction kit; DNA Investigating Kit (QIAGEN, Germany). Seven point five microlitres of each first and second round PCR products were subjected to electrophoresis in a $2 \%$ agarose gel. First round products generated fragment sizes of $378 \mathrm{bp}, 247$ bp and $233 \mathrm{bp}$ for $\left(1^{\mathrm{st}}\right)$ round oligonucleotide PCR primers Hum1.1, Hum1.2 and Hum1.3 respectively. Second round products generated fragment sizes of $247 \mathrm{bp}, 135 \mathrm{bp}, 161$ bp, 228 bp for (2nd) round oligonucleotide PCR primers Hum2.1, Hum2.2, Hum2.3 and Hum2.4 respectively. 
Chandimal, K.M., Yasawardene, S.G., Ruwan, J. Illeperuma - Optimization of DNA extraction protocol using skeletal remains found in Sri Lanka

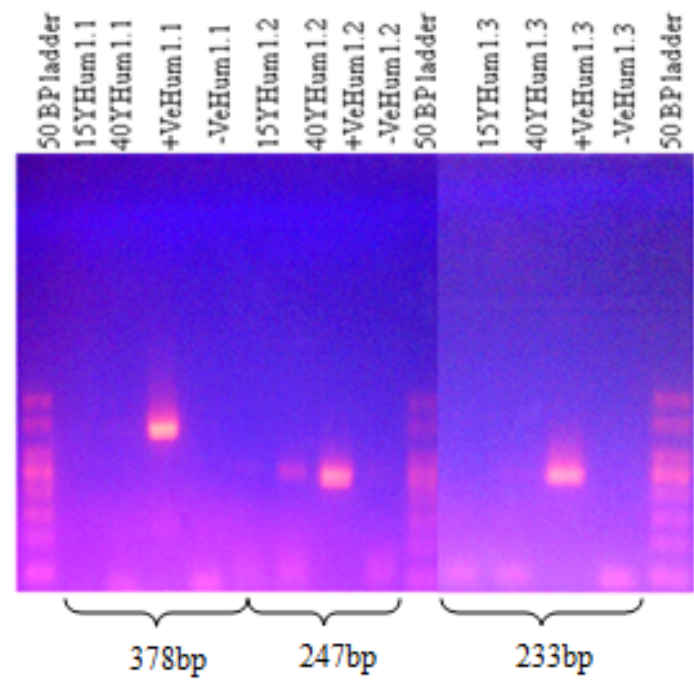

Fig 1.4a

Fig 1.4a. Agarose gel containing $7.5 \mu 1$ of each first-round PCR product and Fig 1.4b Agarose gel containing $7.5 \mu 1$ of each second round PCR product amplified from the extraction done by DNA Investigating Kit (QIAGEN, Germany) of $15 \mathrm{Y}$ and $40 \mathrm{Y}$ bones

DNA bands were obtained with correct size ranges for $15 \mathrm{Y}$ and $40 \mathrm{Y}$ bone amplified by PCR reactions containing ADHum 1.2 primer of first-round PCR products.

DNA bands were obtained from all four systems for $40 \mathrm{Y}$ bone. However, there was no PCR amplification in $15 \mathrm{Y}$ bone except PCR system containing ADHum2.4 primer.

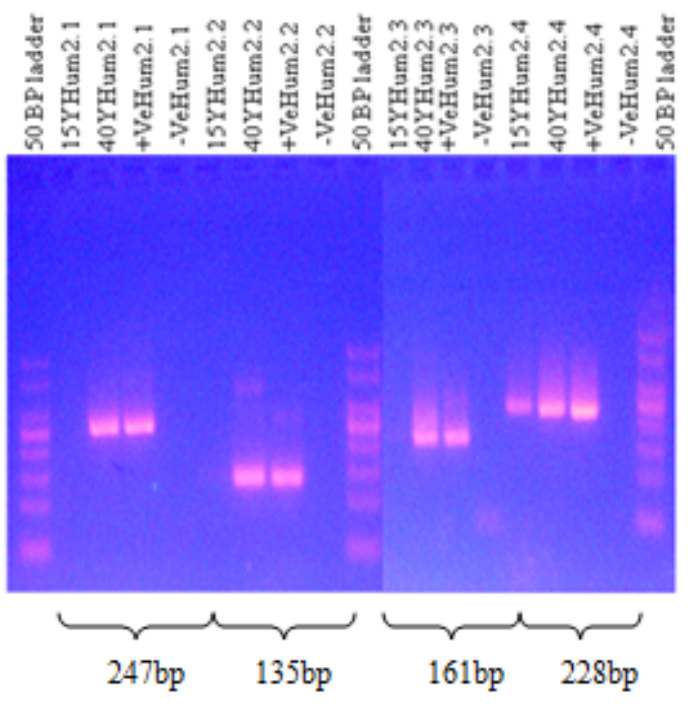

Fig $1.4 b$

\section{Modified phenol chloroform method}

DNA was extracted from old bones of $15 \mathrm{Y}$ and $40 \mathrm{Y}$ using the modified method of phenol chloroform described by Ariffin et al., (2007) ${ }^{[14]}$. Seven point five microlitres of first round and second round PCR products were subjected to electrophoresis in a $2 \%$ agarose gel. First round products generated fragment sizes of $378 \mathrm{bp}, 247$ $\mathrm{bp}$ and $233 \mathrm{bp}$ for (1st) round oligonucleotide PCR primers Hum1.1, Hum1.2 and Hum1.3 respectively. Second round products generated fragment sizes of $247 \mathrm{bp}, 135 \mathrm{bp}, 161$ bp, 228 bp for $\left(2^{\text {nd }}\right)$ round oligonucleotide PCR primers Hum2.1, Hum2.2, Hum2.3 and Hum2.4 respectively. 
Chandimal, K.M., Yasawardene, S.G., Ruwan, J. Illeperuma - Optimization of DNA extraction protocol using skeletal remains found in Sri Lanka

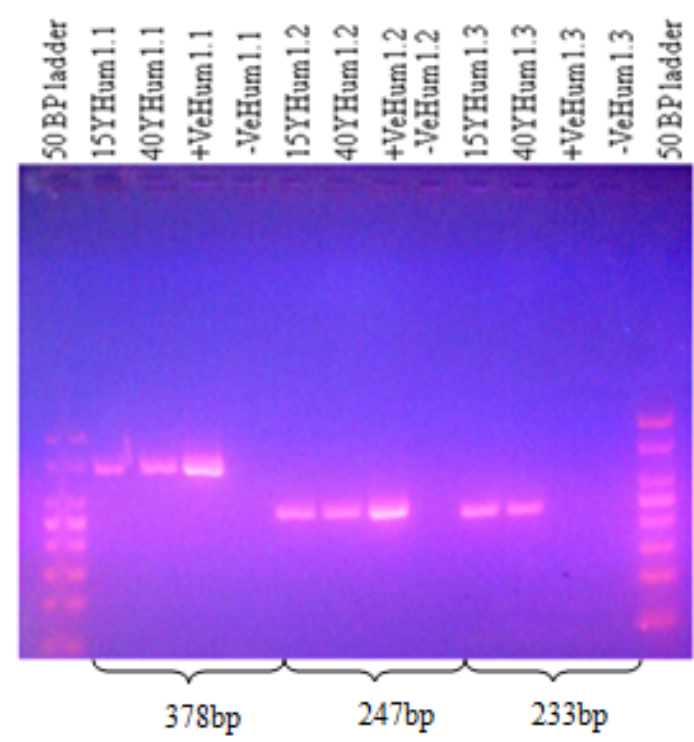

Fig 1.5a

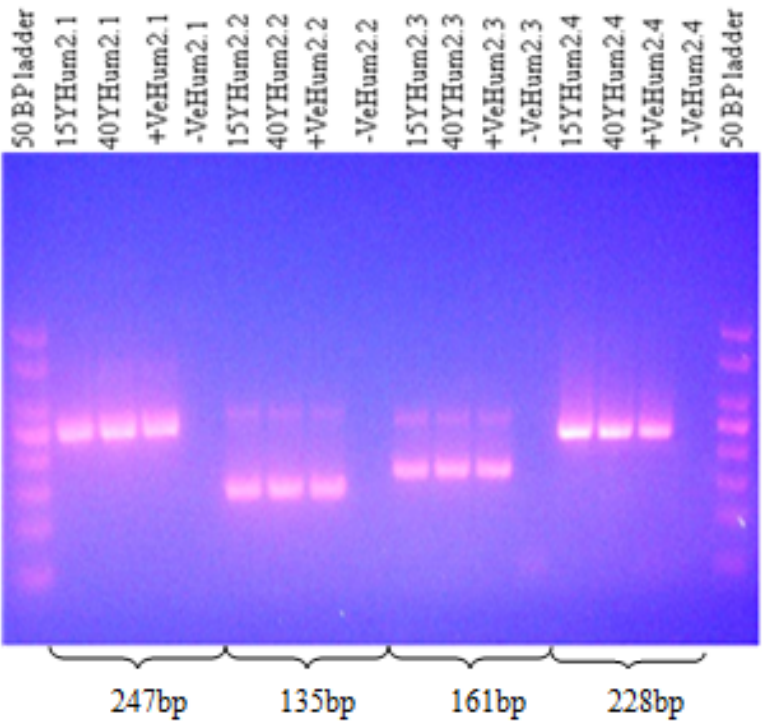

Fig $1.5 b$
Fig 1.5a Agarose gel containing $7.5 \mu \mathrm{l}$ of each first-round PCR product and Fig 1.5b. Agarose gel containing $7.5 \mu \mathrm{l}$ of each second round PCR product amplified from the modified extraction method of phenol-chloroform described by Ariffin et al., (2007) ${ }^{[14]}$ of $15 \mathrm{Y}$ and $40 \mathrm{Y}$ bones

DNA bands were obtained with correct size ranges for all systems in both first and second round PCR products.

\section{Discussion}

Five DNA extracting methods were tested in order to check the feasibility of isolating DNA from bone samples of the present study.

Although, the Chelex based DNA extraction protocol has been successfully extracted highly fragmented DNA from human and animal skeletal remains dated back to 5,400 YBP at temperate countries like
Canada by Newman et al., (2002) ${ }^{[13]}$, this protocol did not yield any DNA from old bone samples used in this study (Fig 1.1a, and 1.1b).

The method of ethanol precipitation enhanced by Dextran blue has yielded DNA of skeletal remains found in Iran in the Middle East (Mohendasan et al., 2004) ${ }^{[14]}$. In this study, DNA extraction protocol - ethanol precipitation enhanced by Dextran blue was not able to yield DNA from both $40 \mathrm{Y} / 15 \mathrm{Y}$ samples (Fig 1.2a, and 1.2b). The DNA extraction protocol - ethanol precipitation enhanced by Dextran blue was modified by changing the consistency of extraction buffer and this modified version of same protocol gave better results for second round PCR amplification (Fig 1.3a, and 1.3b).

The modified version of the protocol published by Ariffin et al., (2007) ${ }^{[15]}$ reporting successful DNA extraction from a 400-year-old bone recovered from Wanli's shipwreck at Dungun sea 
Chandimal, K.M., Yasawardene, S.G., Ruwan, J. Illeperuma - Optimization of DNA extraction protocol using skeletal remains found in Sri Lanka

coast was found to be successful for the present study (Fig 1.4a, and 1.4b). A commercial DNA extraction kit; DNA Investigating Kit (QIAGEN, Germany) also yielded DNA from old bones in this study (Fig 1.5a, and 1.5b).

Contamination with other DNA sources is of the utmost concern when working with old DNA ${ }^{[25,23]}$. Contaminant human DNA can be introduced at any point during the processes of sampling, extraction and finally PCR setup ${ }^{[25,23,28,29]}$. Therefore, strict laboratory procedures have been adhered to minimize such contaminations and this would affect the authenticity of the result of the DNA extract. Negative controls in extraction and amplification procedures were used to detect possible contaminations. PCR control amplifications were performed with multiple non - template PCRs containing aliquots of the reagent with distilled water. These controls were done together with actual template samples to detect sporadic or low copy number contamination as recommended by Eshleman and Smith, $(2001)^{[26]}$. The absence of contaminants of human DNA was confirmed by the absence of amplification (DNA bands) in the negative controls (Fig 1.4a, 1.4b, 1.5a and $1.5 b)$.

It is always recommended to have a dedicated laboratory to handle specimens for DNA studies of old or ancient samples. However, there is a possibility that chemicals, reagents and disposable items such as columns, tubes, pipette tips etc could be contaminated by modern DNA during manufacturing processes ${ }^{[26]}$. Therefore, contamination of DNA extracts with modern DNA can be possible even in a laboratory dedicated for forensic DNA analysis. In the present study, it was demonstrated that strict decontamination procedures were done that has not been used previously for modern DNA testing and decontamination process such as exposure to UV (Ultra Violet radiation) of reagents and equipment during the preparation of old DNA samples was utilized during analysing. Furthermore, $1.0 \%$ of chlorox was used to clean all bench surfaces to eliminate any surface contamination.

Detection of any PCR amplification even after 50 cycles of initial PCR amplification failed for both samples (Fig 1.1a). This observation was in contrast with that of the fresh biological sample (+ve control) (Fig 1.1a). This may be due to a result of very low amount of initial DNA template in the reaction. In order to compensate for the very low amounts of retrieved DNA, a second round (nested) PCR was optimized to increase the specificity and sensitivity of the technique as described in Lertrit et al., (2008) ${ }^{[24]}$.

In this study, we successfully optimized DNA extraction protocol phenolchloroform method which gave better DNA yield from old bone samples. DNA investigation kit gave better DNA yield from the old skeletal remains too. This optimized protocol could be used in forensic DNA analysis, archaeological DNA studies and even ancient DNA studies. 
Chandimal, K.M., Yasawardene, S.G., Ruwan, J. Illeperuma - Optimization of DNA extraction protocol using skeletal remains found in Sri Lanka

\section{Acknowledgement}

University of Sri Jayewardenepura and University Grant Commission, Sri Lanka for financial support granted to the study is highly acknowledged.

\section{Corresponding Author}

Dr. Chandimal, K. M. (PhD)

Department of Anatomy, Faculty of Medicine, Wayamba University of Sri Lanka Tel: +94-711141591

E-mail:kmchandimal@wyb.ac.lk

\section{References}

1. Hoss M., Jaruga P., Zastawny T.H., Dizdaroglu M., Pääbo S. (1996), DNA Damage and DNA Sequence Retrieval from Ancient Tissues, Nucleic Acids Research, 24:13041307.

2. Lindahl T. (1993). Instability and decay of the primary structure of DNA. Nature, 362: 769-715.

3. Gutierrez, G. and Marin, A. (1998). The most ancient DNA recovered from an amber-preserved specimen may not be as ancient as it seems. Molecular Biology Evolution, 15: 926-929.

4. Pääbo S., Poinar H.N., Serre D., Jaenicke-Despre's V., Hebler J., Rohland N., Kuch M., Krause J., Vigilant L., Hofreiter M. (2004). Genetic analyses from ancient DNA. Annu. Rev. Genet., 38: 645679.
5. Leonard, J.A., Wayne, R.K., Wheeler, J., Valadez, R. and Guillen, S. (2002). Ancient DNA evidence for Old World origin of New World dogs. Science, 298: 1613-1616.

Hummel, S., Nordsiek, G. and Herrmann, B. (1992). Improved efficiency in amplification of ancient DNA and its sequence analysis. Naturwissenschaften, 79: 359-360.

7. Hoss, M., Dilling, A., Currant, A., and Paabo, S. (1996). Molecular phylogeny of the extinct ground sloth Mylodon darwinii. Proc. Natl. Acad. Sci. USA 93:181.

8. Bon, C., Caudy, N., de Dieuleveult, M., Fosse, P. and Philippe, M. (2008). Deciphering the complete mitochondrial genome and phylogeny of the extinct cave bear in the Paleolithic painted cave of Chauvet. Proceeding of the National Academy of science USA, 105: 17447-17452.

9. Burger, J., Hummel, S., Hermann, B. and Henke. (1999) DNA preservation: a microsatellite-DNA study on ancient skeletal remains. Electrophoresis, 20: 1722-8.

10. Tuross, N. (1994). The biochemistry of ancient DNA in bone. Experientia, 50: 530-35.

11. Hagelberg, E., Gray, I. and Jeffreys, A. (1991). Identification of the skeletal remains of a urder victim by DNA analysis. Nature, 352: 427 429. 
Chandimal, K.M., Yasawardene, S.G., Ruwan, J. Illeperuma - Optimization of DNA extraction protocol using skeletal remains found in Sri Lanka

12. Yang, D.Y., Eng, B., Waye, J.S., Dudar, J.C. and Saunders, S.R. (1998). Improved DNA extraction from ancient bones using silicabased spin columns. American Journal of Physical Anthropology, 105: 539-543.

13. Newman, M.E., Jillian, S.P., Peter, J.B. and Howard, C. (2002). Identification of archaeological animal bone by PCR/DNA analysis. Journal of Archaeological Science, 29: 77-84.

14. Mohandesan E., Mowla S.J., Noobari A.H., Yaghoobi M.M., and Mesbah-Namin S.A. (2004). Extraction and analysis of ancient DNA from human remains of Masjede Kabood burial site. Iranian Journal of Biotechnology, 2: 236242.

15. Ariffin, S.H.Z., Wahab, R.M.A., Zamrod, Z., Sahar, S., Razak, M.F.A., Ariffin, E.J. and Senafi, S. (2007). Molecular Archaeology of Ancient Bone From 400 Year Old Shipwreck. Asia Pacific Journal of Molecular Biology and Biotechnology, 15(1): 27-31.

16. Vlahovic, M.K. and Kubat. M. (2012). DNA extraction method from bones using Maxwell 16. Leg Med. Tokyo., 14:272-275.

17. Correa, H.S.D., Pedro, F.L.M., Volpato, L.E.R., Pereira, T.M., Seibert, Filho, G., Borges, A.H. (2017). Forensic DNA typing from teeth using demineralized root tips. Forensic Sci Int., 280:164-168.
18. Harrel, M., Mayes, C., Gangitano, D., Hughes, S.S. (2018). Evaluation of a powder-free DNA extraction method for skeletal remains. J Forensic Sci.

19. Ovchinnikov, I.V., Gtherstrom, A., Romanova, G.P., Kharitonov, V.M. and Liden, K. (2000). Molecular analysis of Neanderthal DNA from the northern Caucasus. Nature, 404: 490-493.

20. Reed, F.A., Kontanis, E.J., Kennedy, K.A.R. and Aquadro, C.F. (2003). Brief communication: ancient DNA prospects from Sri Lankan highland dry caves support an emerging global pattern. American Journal of Physical Anthropology, 121: 112-116.

21. Amory, S., Huel, R., Bilić, A., Loreille, O. and Parsons, T.J. (2012). Automatable full demineralization DNA extraction procedure from degraded skeletal remains. Forensic Science International Genetics, 6 (3): 398406.

22. Zgonjanina, D., Mirjana, A., Rashed, A., Stojan, P., Radenko, V., Goran, S. and Danka, T. (2017). DNA analysis from human skeletal remains in forensic casework Forensic Science International: Genetics Supplement Series, 6: e342-e345

23. Poinar, H.N. (2003). The top 10 list: criteria of authenticity for DNA from ancient and forensic samples. International Congress Series, 1239: 575-579. 
Chandimal, K.M., Yasawardene, S.G., Ruwan, J. Illeperuma - Optimization of DNA extraction protocol using skeletal remains found in Sri Lanka

24. Lertrit, P., Poolsuwan, S., Thosarat, R., Sanpachudayan, T., Boonyarit, H. and Chinpaisal, C. (2008). Genetic history of Southeast Asian populations as revealed by ancient and modern human mitochondrial DNA analysis. American Journal of Physical Anthropology, 137(4): 425-40.

25. Yang, D.Y. and Watt, K. (2005). Contamination controls when preparing archaeological remains for ancient DNA analysis. Journal of Archaeological Science, 32: 331336

26. Eshleman, J.A. \& Smith, D.G. (2001). Use of DNase to Eliminate Contamination in Ancient DNA Analysis. Electrophoresis, 22: 4316-4319.
27. Alaeddini, R., Walsh, S.J., Abbas, A. (2010). Forensic implications of genetic analyses from degraded DNA-a review. Forensic Sci Int Genet, 4:148-157.

28. Hebda, L. Foran, D. (2015). Assessing the utility of soil DNA extraction kits for Increasing DNA yields and eliminating PCR inhibitors from buried skeletal remains. J Forensic Sci., 60:13221330.

29. Hebda, L. Foran, D. (2015). Assessing the utility of soil DNA extraction kits for Increasing DNA yields and eliminating PCR inhibitors from buried skeletal remains. J Forensic Sci., 60:13221330. 